\title{
LITHO- AND BIOSTRATIGRAPHY OF LAKE PÄIDRE, SOUTH ESTONIA
}

\author{
Leili SAARSE, Siim VESKI, Atko HEINSALU, Raivo RAJAMAE, \\ and Tõnu MARTMA
}

Eesti Teaduste Akadeemia Geoloogia Instituut (Institute of Geology, Estonian Academy of Sciences), Estonia pst. 7, EE-0100 Tallinn, Eesti (Estonia)

Presented by A. Raukas

Received 16 May 1994, accepted 27 September 1994

\begin{abstract}
Deposits of a small shallow Lake Päidre were studied using litho-, bioand chronostratigraphical methods. The sediment stratigraphy is variable and covers the Allerød (laminated silt), Younger Dryas and Preboreal (silt with moss remains), transition of Preboreal to Boreal (jelly algal gyttja), and Boreal to the recent times (lime gyttja and gyttja). Twenty-six radiocarbon dates have different values, part of them have an apparent age. A characteristic feature of the vegetation history of the surroundings of Lake Päidre is a high share of spruce from the Subboreal onwards and the Quercetum mixtum forest pattern still left in the ancient valleys. The signs of human activities are weak, but traceable between $5000-4000,3500-3000$, and 2100-1500 BP based on the landscape openness and an increase in the mineral fraction in bottom deposits. The lowering of the lake level in the Younger Dryas and Preboreal was replaced by a rise in the Boreal. At the beginning of the Atlantic the lake level was low, but it rose afterwards.
\end{abstract}

Key words: litho-, bio-, and chronostratigraphy; vegetation history; lake-level changes.

\section{INTRODUCTION}

The Sakala Upland is rich in lakes. Their total number is 102 and they cover an area of 1590 ha. This is approximately four lakes per $100 \mathrm{sq} \mathrm{km} \mathrm{(Mäemets,} \mathrm{1983).} \mathrm{The} \mathrm{lakes} \mathrm{are} \mathrm{small} \mathrm{in} \mathrm{size,} \mathrm{except} \mathrm{for} \mathrm{four}$ lakes with a surface area of more than 100 ha. The lakes usually occupy closed basins in the hilly moraine topography or drainage basins in ancient valleys.

The geology of five lakes (Viljandi, Oisu, Kariste, Päidre, and Võistre; Fig. 1) has been studied (Caapce, 1994; Caapce \& Сapв, 1986) and seven pollen diagrams compiled for the region: Mõonnaste (Lõokene \& Pirrus, 1979), Viljandi and Sinialliku (Lõokene, 1979), Võistre and Pirmastu (Сaаpce \& Сарв, 1986), and two diagrams from Lake Päidre (the present paper). Three well-dated pollen diagrams from Nigula and Mõksi mires on the southwestern slope of the Sakala Upland complement this list (Сарв \& Ильвес, 1976). The earlier research has been focused mostly on the overgrown part of the lake (marginal fens) (Männil, 1964; Пиррус, 1969; Lõokene \& Pirrus, 1979). The first corings 
on the lakes of the Sakala Upland, including Lake Päidre, were made in 1982 (Саapce \& Сарв, 1986; Sats, 1983) within the frame of the IGCP Project 158b "Palaeohydrology of the Temperate Zone During the Last 15000 years". The present paper follows the example of the presentations of this project (Berglund, 1979).

\section{SITE DESCRIPTION}

Päidre $\left(58^{\circ} 16^{\prime} \mathrm{N}, 25^{\circ} 30^{\prime} \mathrm{E}\right)$ is a small shallow lake located $50.6 \mathrm{~m}$ a.s.l., with a surface area of 32.8 ha, mean depth of $1-2 \mathrm{~m}$, and maximum depth of $3.6 \mathrm{~m}$. The lake lies about $10 \mathrm{~km}$ southwest from the town of Viljandi. Lake Päidre occupies a melt-out depression in the Heimtali Valley, which runs north-south from the Raudna River to the middle course of the Kõpu River (Fig. 1). The shores of the lake are paludified, the catchment was drained in the 1980s and thereafter

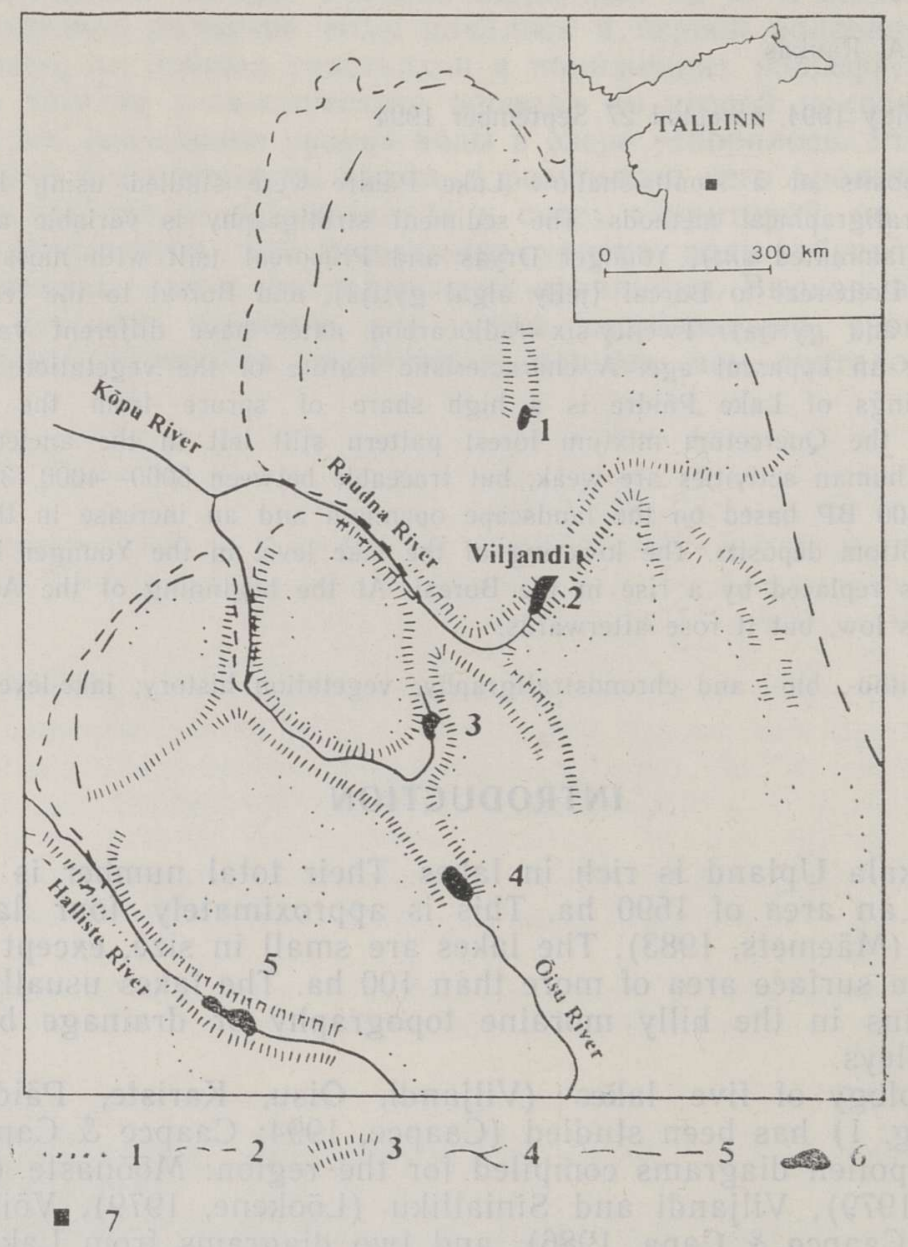

Fig. 1. Location of the studied lakes in the northern part of the Sakala Upland. 1 distribution of the local ice lake; 2 the Baltic Ice Lake; 3 ancient valleys; 4 rivers; 5 the upland border (after Lõokene, 1961); 6 studied lakes: 1 - Võistre, 2 - Viljandi, 3 - Päidre, 4 - Oisu, 5 - Kariste; 7 study area. 
cultivated. Lake Päidre has an inflow from southeast via the Lollioja and from north and south by ditches and additional feed by ground and surface run-off. The outlet via Naba Brook leads to Lake Turva and then to the Rimmu River. The catchment area is about three times as large as the lake itself. It is covered mainly by fields and cultivated meadows where pastoral farming predominates. During our first field work in this area in 1973 the catchment was covered by dense Betula and Salix groves.

\section{METHODS}

We carried out 11 corings, partly from ice, partly from an anchored raft, on lake proper and 35 corings on its overgrown basin with a Belarus peat sampler to trace the bedding of the bottom deposits (Fig. 2 ). The subsurface soft sediments from core $45 \mathrm{~A}$ were taken using a tube piston corer and subsampled on the spot. Three cores (Nos. 35, 45 , and 582) were analysed by means of chemical composition, pollen, and spores. Cores were cut into 1 or $2 \mathrm{~cm}$ slices and the standard chemical treatment ( $\mathrm{KOH}$, acetolysis) was applied for pollen analysis. A pollen diagram was plotted with the TILIA*TILIA GRAPH computer program worked out by Grimm (1992). The samples for radiocarbon dating were taken from cores Nos. 45, 45A, and 35 .

The organic matter content was determined at low $\left(500{ }^{\circ} \mathrm{C}\right)$ and high $\left(825^{\circ} \mathrm{C}\right)$ temperatures. The difference between them was multiplied by 2.27 and regarded as the carbonate content.

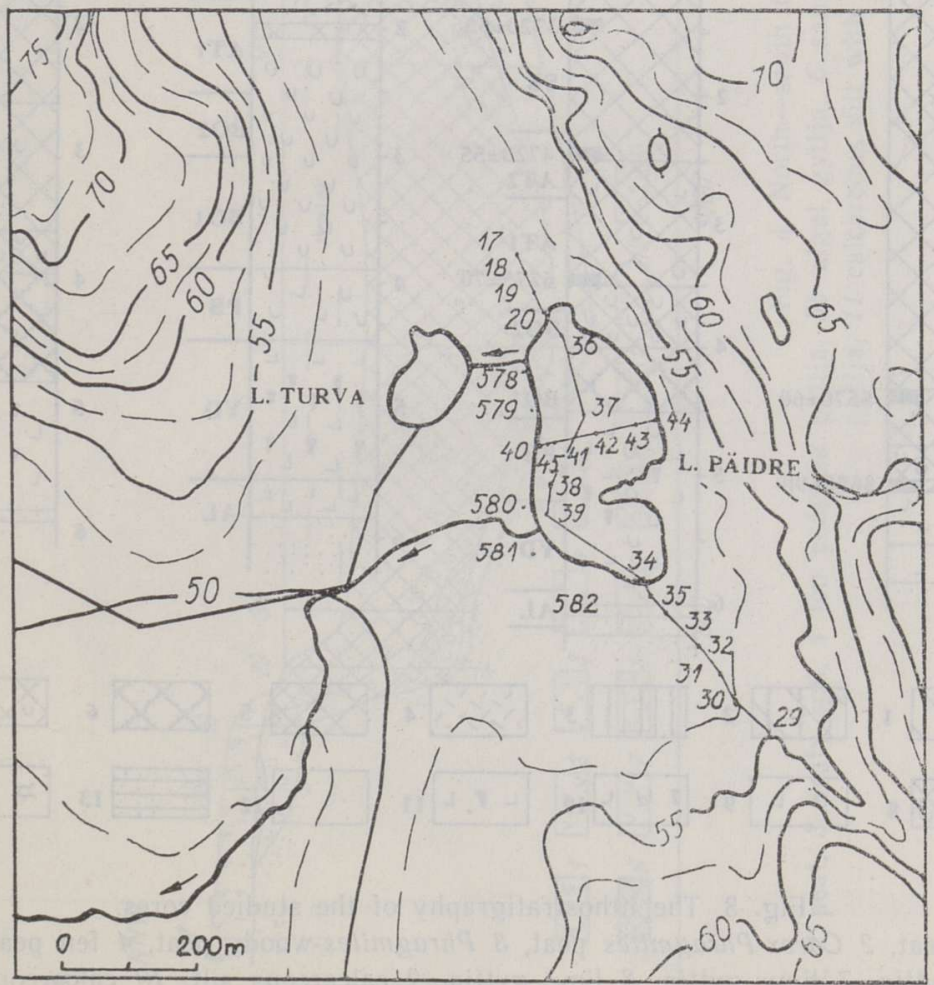

Fig. 2. Selected corings at Lake Päidre. 


\section{LITHOSTRATIGRAPHY}

The lithostratigraphy of the bottom deposits in the basin of Lake Päidre varies between several facial transitions from lacustrine lime in the littoral zone to limy gyttja in the profundal zone. This complicates the correlation of the cores (Fig. 3).

Two transects from lacustrine deposits (Figs. 4, 5) and two from fen deposits were carried out. The basal beds are Devonian sandstones, overlaid with pink laminated silts that contain redeposited Devonian material accumulated in the proglacial environment at the transition of the Older Dryas-Allerød. In core No. 45 this bed is only $0.2 \mathrm{~m}$ thick at a depth of $6.2-6.0 \mathrm{~m}$ (Figs. 3, 5).

The next bed is slightly calcareous silt without visible lamination $(6.0-4.55 \mathrm{~m})$ with moss remains in the littoral and diffuse organic matter in the profundal part of the lake. The colour of the silt varies from greenish to dark grey. Its thickness is about $1-1.5 \mathrm{~m}$. The silt accumulated in the Allerød and Younger Dryas, its uppermost moss-rich portion during the Preboreal. In the deeper central and southern parts

CORE 35

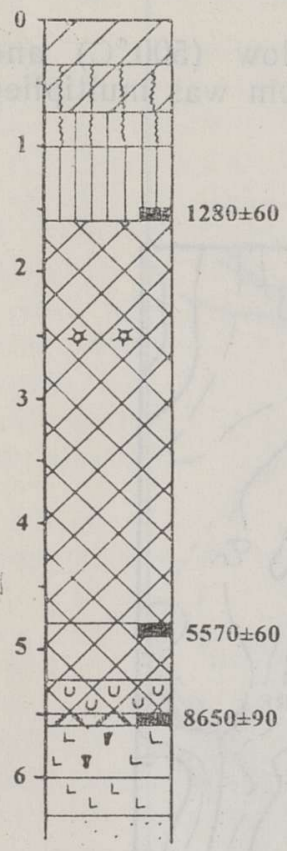

CORE 45

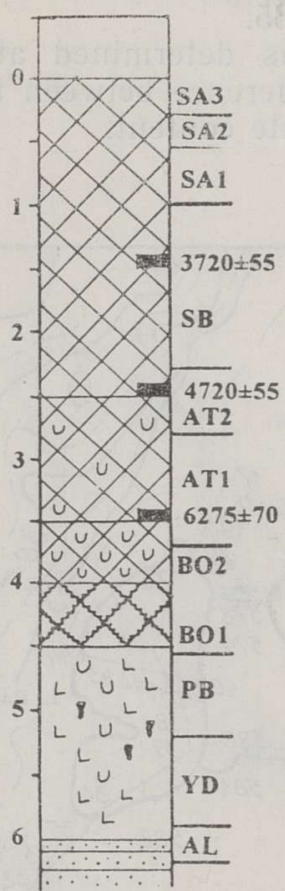

CORE 582

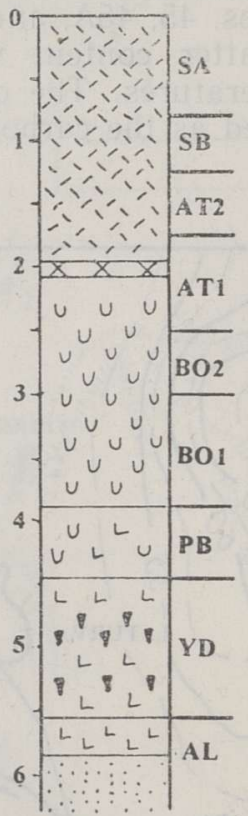

CORE $45^{+}$

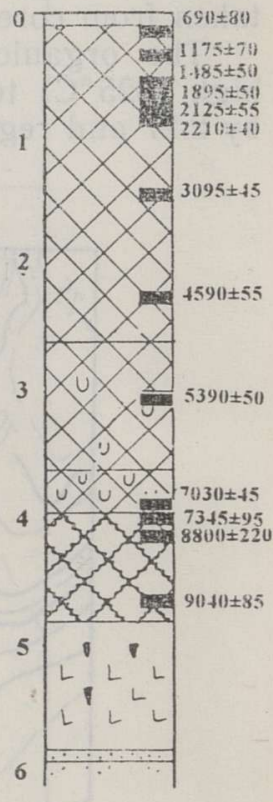

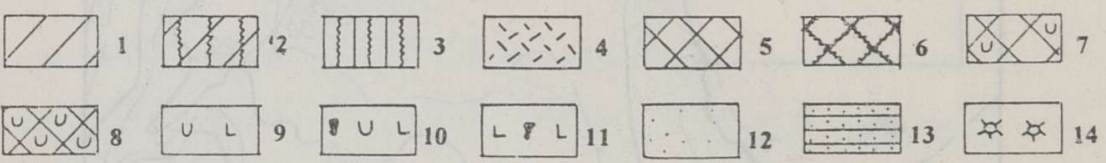

Fig. 3. The lithostratigraphy of the studied cores.

1 Carex peat, 2 Carex-Phragmites peat, 3 Phragmites-woody peat, 4 fen peat, 5 gyttja, 6 algal gyttja, 7 limy gyttja, 8 lime gyttja, 9 calcareous silt, 10 calcareous silt with moss remains, 11 silt with moss remains, 12 sand, 13 laminated sand, 14 fruits of Trapa natans. 


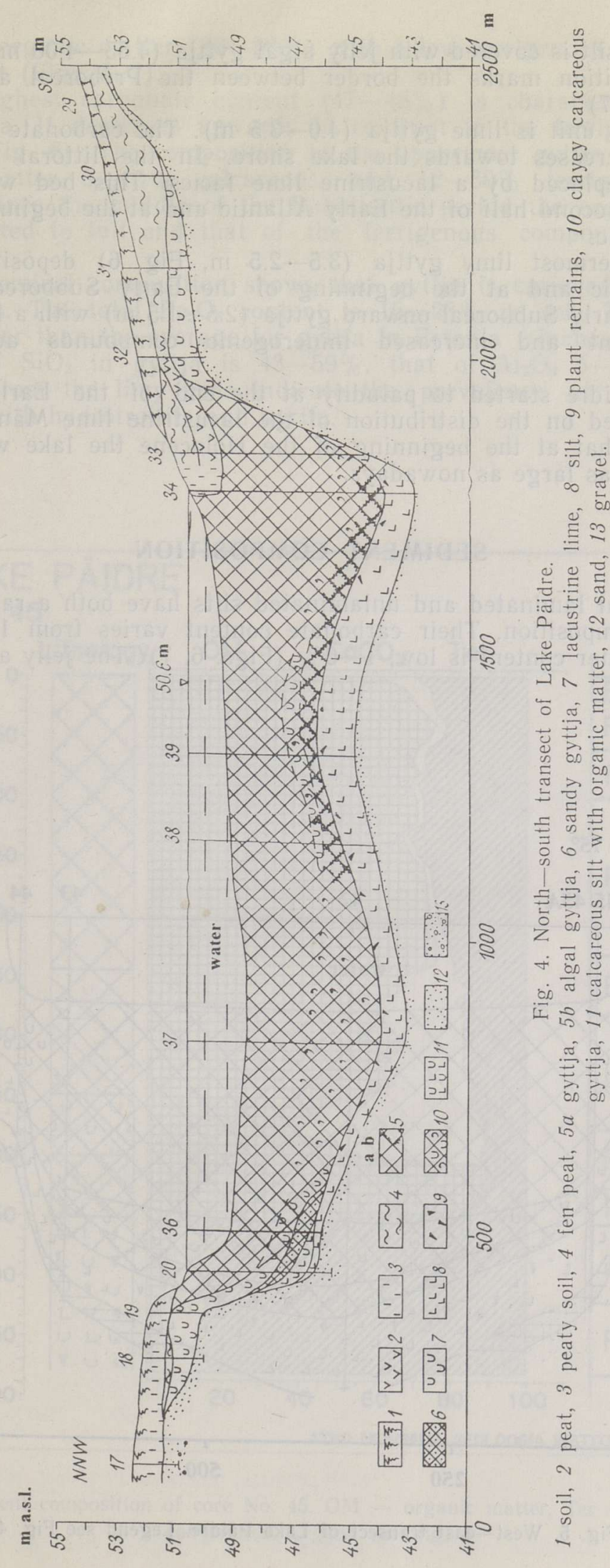

4 Eesti TA Toimetised. G 11995 
of the lake silt is covered with jelly algal gyttja $(4.55-4.00 \mathrm{~m})$. A sharp upper transition marks the border between the Preboreal and Boreal (Figs. 3, 6, 7).

The next unit is lime gyttja $(4.0-3.5 \mathrm{~m})$. The carbonate content in this bed increases towards the lake shore. In the littoral zone lime gyttja is replaced by a lacustrine lime facies. This bed was formed during the second half of the Early Atlantic and at the beginning of the Late Atlantic.

The uppermost limy gyttja $(3.5-2.5 \mathrm{~m}$, Fig. 6) deposited in the Late Atlantic and at the beginning of the Early Subboreal periods. From the Early Subboreal onward gyttja $(2.5-1.5 \mathrm{~m})$ with a low calcareous content and increased minerogenic compounds accumulated (Fig. 6).

Lake Päidre started to paludify at the end of the Early Atlantic period. Based on the distribution of the lacustrine lime Männil (1964) concluded that at the beginning of the Holocene the lake was almost eight times as large as nowadays.

\section{SEDIMENT COMPOSITION}

The basal laminated and unlaminated silts have both a rather homogeneous composition. Their carbonate content varies from 10 to $16 \%$, organic matter content is low, $1-6 \%$ (Figs. 6,7 ). The jelly algal gyttja

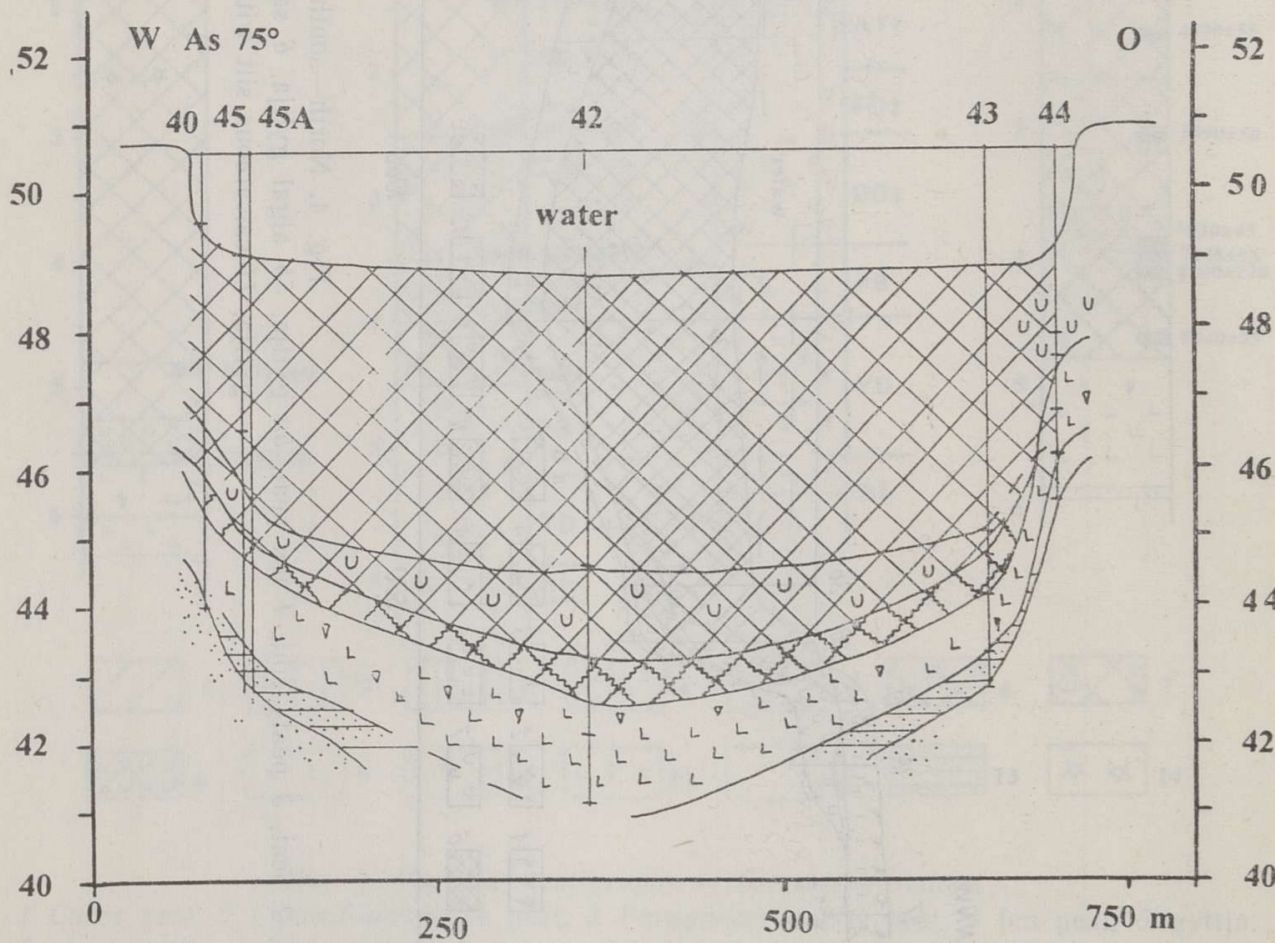

Fig. 5. West-east transect of Lake Päidre. Legend see Fig. 4 
is rich in organic matter $(86-90 \%)$ with a low terrigenous and carbonate content (Figs. 6, 7).

The highest carbonate content $(47-48 \%)$ is characteristic of the limy gyttja. It decreases upwards in contrast to the terrigenous compounds (Fig. 6). The composition of the uppermost gyttja is $60-78 \%$ organic matter, 6-10\% calcareous, and 12-30\% terrigenous compounds. Since the middle of the Subatlantic period the organic matter curve started to fall and that of the terrigenous compounds to rise (Fig. 6).

The chemical composition shows that gyttja is enriched with ferric compounds. The total $\mathrm{Fe}_{2} \mathrm{O}_{3}$ content is $15-23 \%$ in ash. This is $3-4$ times higher than the average for gyttja in Estonia (Caapce, 1976). The content of $\mathrm{SiO}_{2}$ in gyttja is $43-59 \%$, that of $\mathrm{Al}_{2} \mathrm{O}_{3} 5-12 \%$. X-ray analyses from the limy beds indicate the prevalence of calcite and dolomite with hydrotroilite and pyrite.

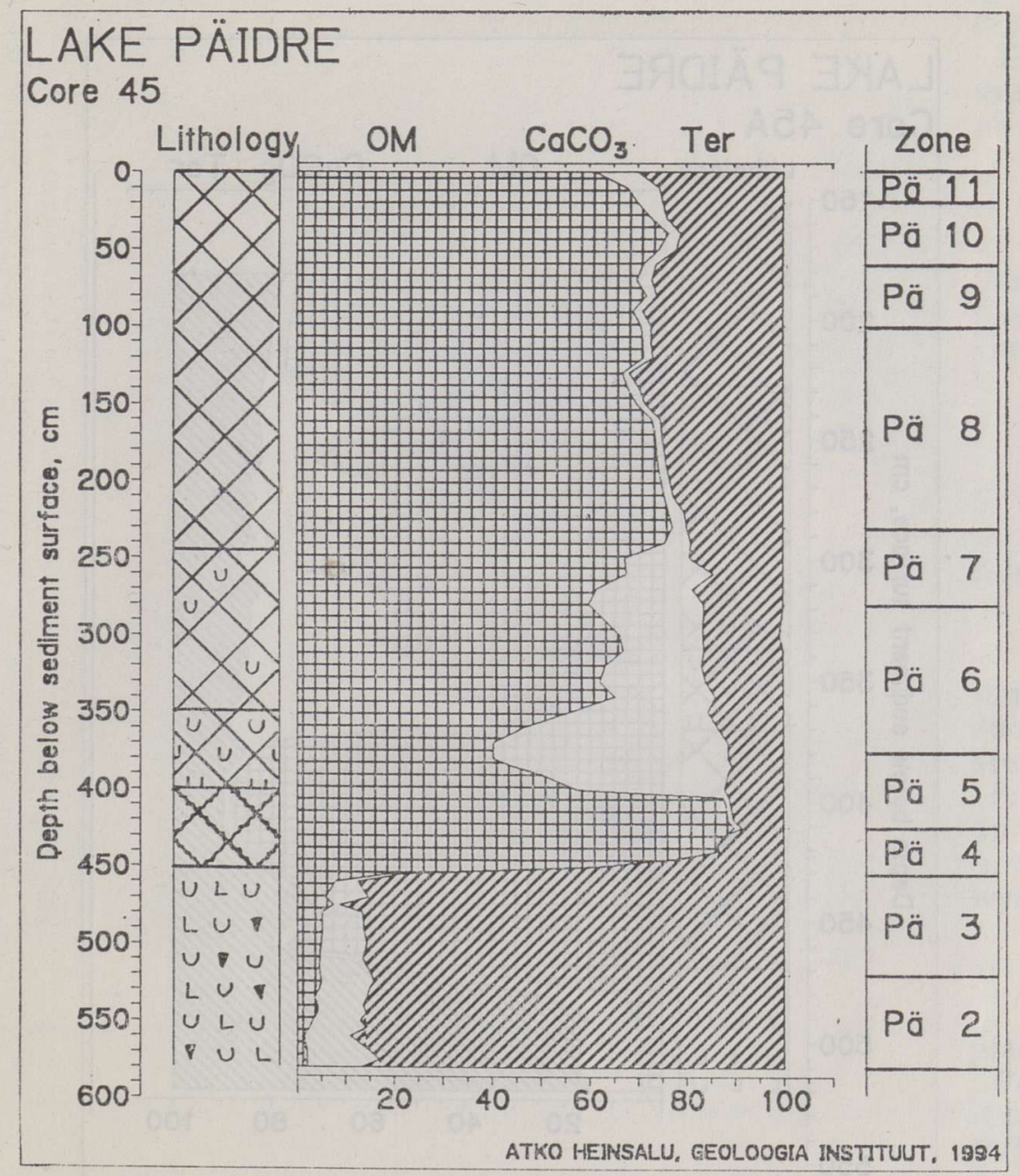

Fig. 6. Sediment composition of core No. 45. OM - organic matter, Ter - terrigenous compounds. Legend see Fig. 4. 


\section{POLLEN STRATIGRAPHY}

Eleven local pollen assemblage zones (PAZ) have been distinguished.

\section{Pä 1, Pinus-NAP zone (6.23-5.85 m)}

This PAZ has been divided into two subzones. The lower part of the PAZ is characterized by abundant Gramineae, Cyperaceae, Artemisia, and Chenopodiaceae. Thus it could have formed during the transition of the Older Dryas/Allerød or at the beginning of Allerød (after Mangerud et al., 1974). The sediments contain Betula, Pinus, and Picea pollen. The last is considered to have been long-distance transported or, more probably, redeposited. The upper part of this zone $(6.15-5.85 \mathrm{~m})$ is characterized by high Pinus $(50-60 \%)$ and low Betula (less than $20 \%$ ) frequencies. The Betula nana value has decreased to $20 \%$. Gramineae, Cyperaceae, Artemisia, and Chenopodiaceae are abundant, though less frequent than in the previous subzone.

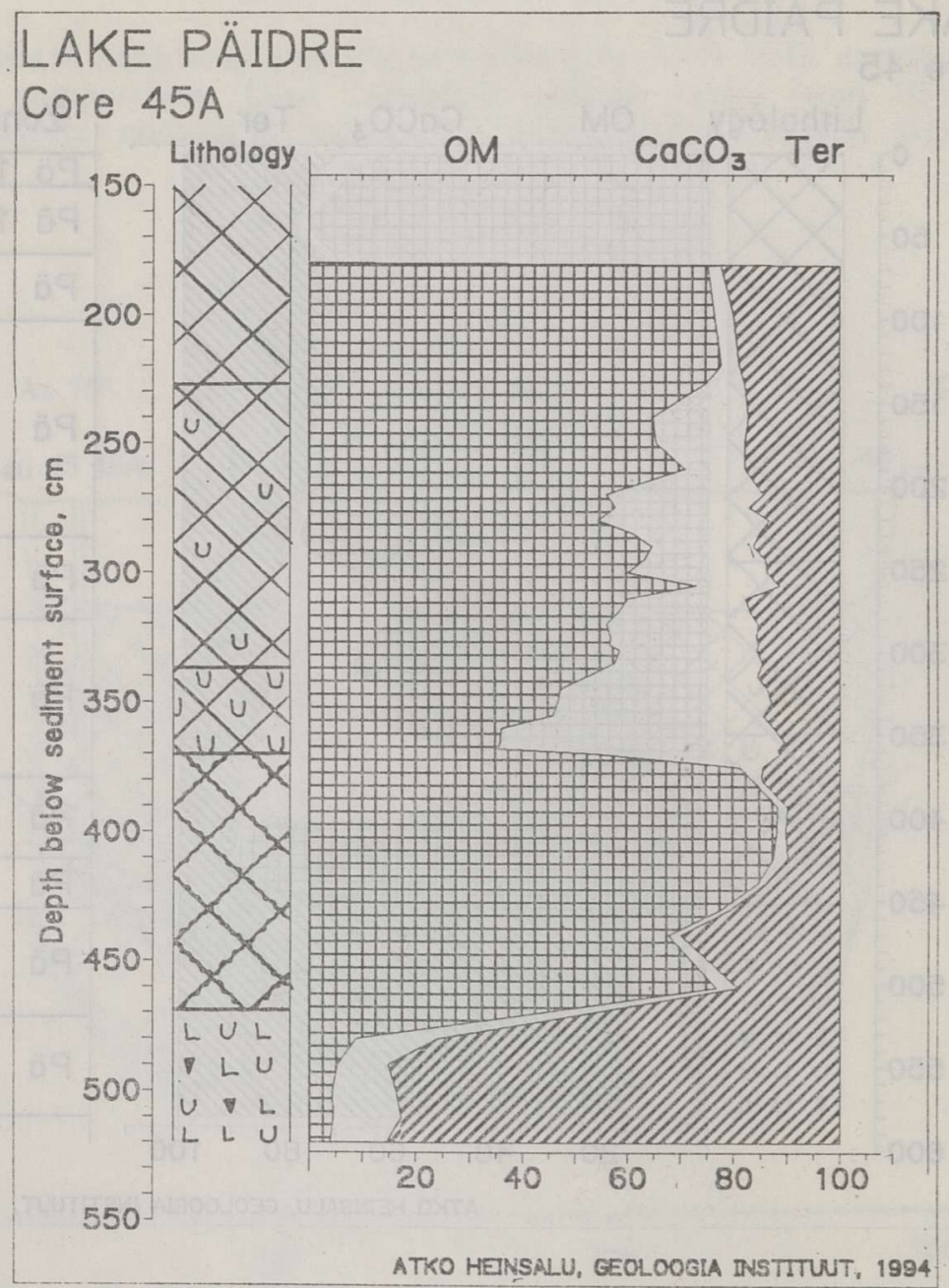

Fig. 7. Sediment composition of core No. 45A. Legend see Figs, 4 and 6 . 


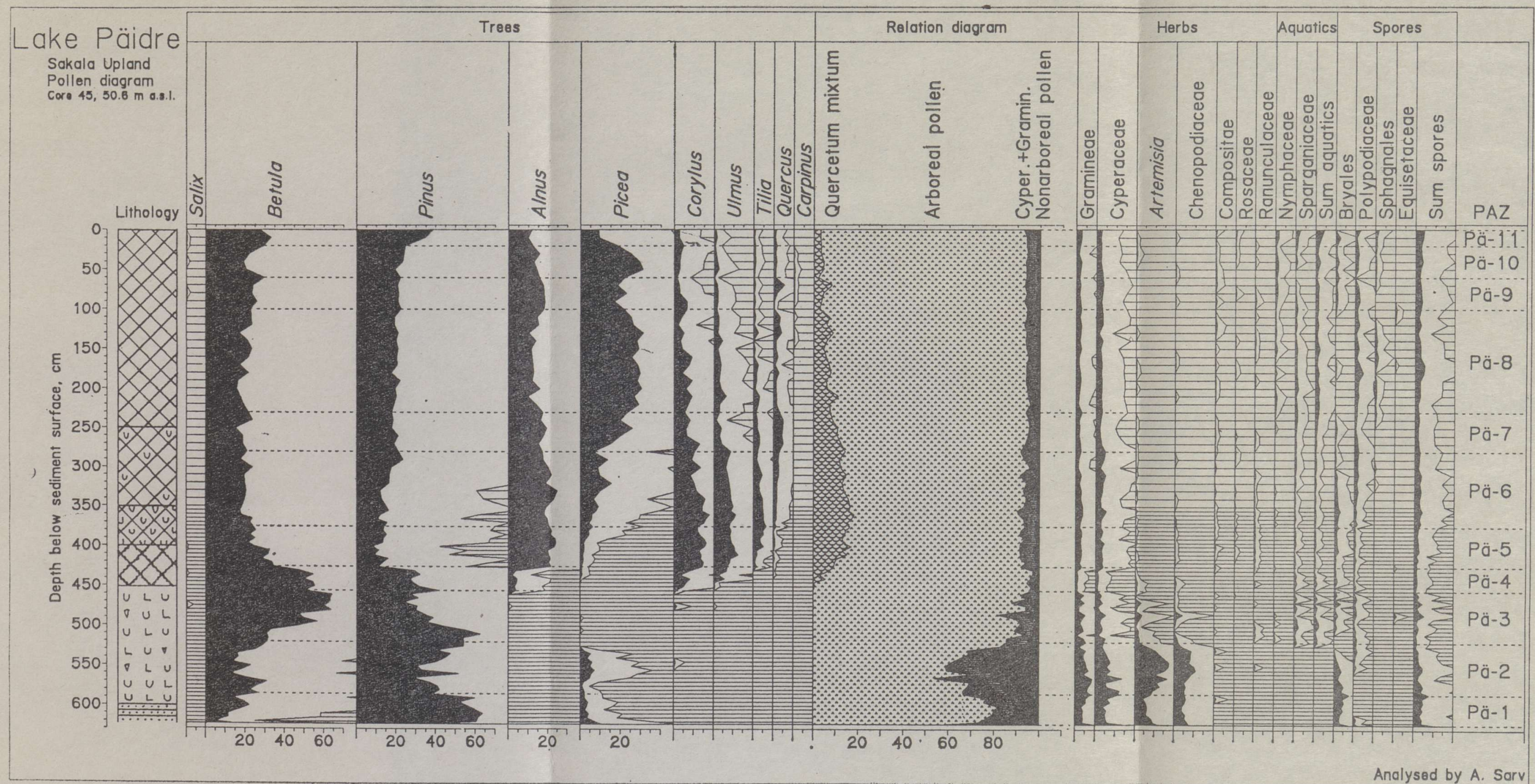

Fig. 8. Pollen composition of the deposits of Lake Päidre (core No. 45). Lithology see Fig. 3. 

Pä 2, NAP zone (Artemisia-Chenopodiaceae) (5.85-5.2 m)

The lower limit of the PAZ is defined by a sharp decrease in Pinus (from 60 to $40 \%$ ) and a pronounced increase in Cyperaceae and Artemisia. Artemisia is a heliophile and is usually associated with unstable soils or continental climate (Kristiansen et al., 1988). The pollen of Compositae and Ranunculaceae appear. The AP frequency decreases from 80 to $56-60 \%$ and that of NAP increases from 20 to $40-42 \%$ (Fig. 8).

\section{$\mathrm{Pä} \mathrm{3,} \mathrm{Betula} \mathrm{zone}(5.2-4.55 \mathrm{~m})$}

The lower boundary is defined by a rise in Betula and a sharp decrease in Artemisia and Chenopodiaceae. In the uppermost part of this PAZ the first grains of Ulmus, Alnus, and Corylus appear. Sparganiaceae and Nymphaceae pollen is present together with spores of Bryales and Polypodiaceae. Equisetum forms a single peak (Fig. 8).

\section{Pä 4, Pinus-Betula zone $(4.55-4.25 \mathrm{~m})$}

The lower limit of the PAZ is at the rise of Pinus and the decrease of Betula. It coincides with the empirical limit of Alnus and Corylus. The upper limit is at a sharp increase in Alnus and the arrival of Tilia. Quercus immigrated almost simultaneously with Ulmus. The curves of Gramineae and Cyperaceae have decreased remarkably. The total AP has its maximum.

\section{Pä 5, Ulmus-Alnus-Corylus zone $(4.25-3.75 \mathrm{~m})$}

Pinus and Betula are in a steep decline at the lower PAZ limit; Alnus and Corylus rise sharply. During a very short period the pollen values of Alnus increase from 2 to $22 \%$. Ulmus meets its maximum $(13 \%)$, Corylus increases up to $15 \%$.

\section{Pä 6, Tilia-Alnus-Ulmus zone $(3.75-2.8 \mathrm{~m})$}

The lower limit of the PAZ is defined by the maximum of Tilia and the rational limit of Quercus and Picea. Betula is stable, Pinus is low and its percentage variable. The ratio of AP/NAP is high and stable.

\section{Pä 7, Quercus zone (2.8-2.3 m)}

The lower boundary of this PAZ is determined by a pronounced increase in Quercus and Picea; the upper limit by a sharp decline in Quercus. Alnus, Ulmus, and Corylus decrease slowly. The share of Tilia pollen reaches its peak in the middle of the PAZ. Betula and Pinus have stable low values. NAP is low and stable, around $7-8 \%$. In the middle of the PAZ Nymphaceae stabilizes, Sparganiaceae increases, and Sphagnum makes a continuous curve. Polypodiaceae is variable, Bryales decreases.

\section{$\mathrm{Pä} 8$, Picea zone $(2.3-1.0 \mathrm{~m})$}

At the lower limit of the PAZ Picea and Quercus change their places. Betula is variable, around $18-20 \%$, Pinus is stable around $20 \%$, Picea has a remarkable maximum about $30 \%$. Tilia and Quercus have several peaks. They decrease slowly together with Ulmus. In the upper part of the PAZ Carpinus appears and makes a continuous curve. NAP is low and stable. The share of the pollen of aquatic plants has increased, especially that of Nymphaceae and Sparganiaceae. The frequency of the spores of Sphagnales and Polypodiaceae has also increased. 
Pä 9, Betulä-Alnus zone (1.0-0.6 m)

Alnus increases on the account of Picea. Pinus is still low and stable, Betula has increased to $30 \%$. Ulmus, Tilia, Carpinus, and Corylus are low, Quercus makes a noticeable peak at the upper limit of the zone. Gramineae and Cyperaceae are low and stable; Rosaceae, Ranunculaceae, and Compositae are variable. Nymphaceae increases and Sparganiaceae decreases. Sphagnales is missing in the middle of the PAZ.

Pä 10, Picea zone $(0.6-0.2 \mathrm{~m})$

Betula has diminished to $10 \%$, Pinus increases and constitutes up to $27 \%$ at the upper zone limit. Picea has a maximum around $30 \%$ after its low values. Alnus keeps around $10 \%$ and decreases upwards. QM is low: Ulmus 2\%, Tilia and Quercus about 1\% (Fig. 8). Carpinus is still present. NAP is low and stable. The curves of Sparganiaceae, Polypodiaceae, and Sphagnales rise.

\section{Pä 11, Pinus-Betula zone $(0.2-0.0 \mathrm{~m})$}

Picea decreases, Carpinus becomes extinct, Betula and Pinus pollen curves rise. Pollen of Ulmus, Tilia, and Quercus is present but with the same low values as in the previous PAZ. The total AP value is high, about $90 \%$, and has only a very slight decrease. Nymphaceae and Sparganiaceae together with Sphagnales and Polypodiaceae have a peak in the surface samples.

\section{VEGETATIONAL HISTORY}

As the main features of the history of vegetation on the Sakala Upland were described already by Pirrus (Пиррус, 1969), here a brief summary is given, stressing the new evidences of the last research.

During the Allerød Pinus exceeds the percentage of Betula in both diagrams of Päidre. Allerod has been divided into two parts in South Estonia. The earlier part with a high Betula and later with the predominance of Pinus is described as established open Pinus forest (Пирpyc, 1969). Still, there is a possibility that the high share of Pinus in Päidre does not show the Late Allerød Pinus forest but together with the distinct peak in NAP indicates the very open conditions where most of the AP pollen is of long-distance transport origin. Following the vegetation establishment Betula immigrates and presses down the pollen shares of Pinus and NAP. These conclusions are in good accordance with European palaeovegetation maps (Huntley, 1990)

In the Younger Dryas the share of trees considerably decreases, but spruce pollen has increased to $5-6 \%$ (in the fen diagram up to $14 \%$; Männil, 1964, p. 211). This has been suggested as proof that spruce should have grown not far from the locality (Пиррус, 1969). The macrosubfossil studies show the existence of spruce in Eastern Fennoscandia even in the Late Glacial period (Vasari, 1986). We think the percentage of spruce pollen could be high also due to the low pollen productivity of the surrounding area allowing the resedimented spruce pollen to show up better. In Päidre the high Pinus share in the lower part of the sediments correlates well with the above-discussed open/cold periods of Allerød and the Younger Dryas. As a whole the vegetation around Päidre was of tundra type rich in Artemisia.

Betula and Pinus were the dominant trees in the Preboreal. Here again the high Pinus at the beginning of the period shows open conditions, long-distance transport of AP (Pinus) pollen, and the establishment of Betula open forest tundra/forest towards the end of the zone 
when also the AP/NAP ratio becomes dominated by AP. In zone Pä 4 Pinus could at last spread shortly after the light-requiring elements of the local vegetation could not hold their ground and diminished after the expansion of Corylus and Alnus. This so-called protocratic phase in the forest history became to an end with the immigration and spread of the temperate deciduous trees (Iversen, 1958). These shade-tolerant and long-lasting trees supplanted the protocratic communities and formed the mesocratic phase (Vasari, 1986; Hyvärinen, 1987).

In the Atlantic time the tree vegetation became more complex and in the middle of the Atlantic the QM forest stabilized. Tilia occupied the well-drained soils; Corylus, Ulmus, Alnus, and Quercus grew on damper soils (Andersen et al., 1983).

The mesocratic phase was succeeded by the telocratic one, manifested by a decrease in temperature and the expansion of late-immigrating taxa, such as Picea, Fagus, and Carpinus (Hyvärinen, 1987). The Ulmus decline, which occurred about 5000 BP, was followed by the expansion of Quercus and Picea. Picea forest occurred here earlier than formerly supposed. The composition of forest was drastically changed: Ulmus and Tilia were suppressed and Picea became dominant. Spruce remained dominant for several millennia. The rapid expansion of spruce forest and the retreat of thermophilous trees is usually explained by the climatic deterioration and the degradation of soils (Berglund, 1966)

The signs of human activities at Päidre are very weak, being mostly located outside the known dwelling places of prehistoric people. The Mesolithic Simusaare settlement is located on the northern coastal area of Lake Võrtsjärv, not far from the Early Neolithic Valma and Kivisaare sites. Stray finds of the Kunda Culture are known from Lepakose, Umbusi, Mõksi, and Jälevere (Jaanits, 1968, 1990); Roman Iron Age tarand graves have been found at Karksi. Nevertheless, the surroundings of Lake Päidre are poor in archaeological finds. The stone graves at Heimtali, not far from Lake Päidre, are the only archaeological finds there.

Three peaks in the oak curve $(2.9-2.4 \mathrm{~m}$, between $5000-4000 \mathrm{BP}$; $1.5-1.1 \mathrm{~m}, 3500-3000 \mathrm{BP}$; and $0.8-0.6 \mathrm{~m}, 2100-1500 \mathrm{BP}$ ) may have occurred due to human activity, indicating the landscape openness. The same levels are marked by substantial increases in the mineral component in the sediments (Fig. 6). Pollen of the plants from open-land vegetation remains sparse, suggesting that there was no grazing ground near the site (Andersen et al., 1983).

Forest composition changed again about $2800 \mathrm{BP}$. The area of spruce forest decreased. Alder, later oak stands increased. This could be connected with a lake-level rise and a largening alder rim around the lake. Also decreasing land cultivation may have been the reason as the content of mineral particles in the sediment also decreased about 30002200 BP. The general decline in farming facilitated the expansion of Betula and Alnus, which regenerate quickly and flower early (Iversen, 1941; Molloy \& O'Connell, 1987). Since 1100 BP spruce and alder are suppressed and pine-birch forest starts to dominate. This marks the final telocratic phase - disappearance of temperate trees and a return to open pine and birch woodland. In the modern vegetation Picea and Betula are dominant. Pinus, Populus, and Alnus are mostly growing on slopes (Laasimer, 1965). Fraxinus forms single groves in ancient valleys. Betula nana meets its southern biogeographical limit in the central part of the Sakala Upland. 


\section{LAKE-LEVEL CHANGES}

The following information was used for reconstructing the lake-level changes in Päidre: (a) carbonate layers and lenses in the gyttja of the profundal transect (Fig. 4); (b) the changes in sedimentation rate; (c) the alternation of organic-rich and carbonaceous deposits; and (d) the composition of aquatic pollen and the results of the mollusc analysis (Männil, 1964)

The first signs of changes in the lake level may be seen at the Allerød/Younger Dryas transition. Then the sedimentation of laminated sands was replaced by silt rich in Bryales mosses. This indicates the shallowing of the water depth in the Younger Dryas, especially toward its end. The low water-level conditions continued at the beginning of the Preboreal, as in the littoral sequence peaty lacustrine lime consisting overwhelmingly of shallow-water molluscs accumulated.

The lake level started to rise at the end of the Preboreal. It stayed rather high at the beginning of the Boreal, evidenced by the accumulation of algal gyttja and the decreased number of shallow-water molluscs (Männil, 1964). During the Early Boreal there was a short-term decrease in the lake level. The number of molluses and their variability increased, especially those of such shallow-water taxa as Physa fontinalis (Männil, 1964). This lowering is not reflected in the profundal core, where algal gyttja continued to accumulate. At the end of the Early Boreal and in the Late Boreal the shallow-water mollusc taxa disappeared and the total number of mollusc taxa diminished. Algal gyttja accumulated in the deeper part of the lake.

At the beginning of the Atlantic period the water level of the lake lowered. The accumulation of algal gyttja was replaced by the accumulation of lacustrine lime, even in the profundal part of the lake. The highest occurrence of the shallow-water mollusc taxa is consistent with this. After that the lake level rose and it stayed rather high throughout the Atlantic with one short-term lowering in the middle, fixed by clianges in the malacofauna and the sedimentation of carbonates in the profundal part of the lake. Since the Subboreal the lake started to overgrow. This is an evidence of the low water stand.

Once again a change in the lake level is traced in the middle of the Subatlantic. The composition of aquatic pollen (disappearance of Sparganiaceae and low Sphagnales, increase in Nymphaceae pollen), decreased calcareous and increased organic matter content are indicative of a lake-level rise about 1000-1500 BP.

\section{CONCLUSIONS}

Lake Päidre has a variable sediment lithology. Organic-rich deposits alternate with calcareous ones. This refers to changes in climate, water budget, trophic status, and hydrological conditions. The bottommost gyttja is enriched with ferric compounds, indicating that during the Early Holocene the role of the ground water input to the lake was greater than today.

Four main stages in the history of Lake Päidre are distinguished: (1) large, (2) oligotrophic, (3) alkalitrophic, and (4) eutrophic stage. During the first stage Lake Päidre was part of a local proglacial lake, whose arms flooded the ancient valleys (Fig. 1). The Baltic Ice Lake water did not reach the Päidre basin. Nevertheless, its area was larger at that time than in modern times. Silts with identical lithological composition accumulated in the deeper part of the basin throughout the 
Allerød, Younger Dryas, and Preboreal not affected by the drastic climatic change at the Late Pleistocene/Holocene boundary. In the littoral zone of the lake peaty lacustrine lime started to accumulate during the Preboreal. The lake area exceeded the modern one almost 8-10 times (Männil, 1964).

During the oligotrophic stage (the Early Boreal period) algal gyttja accumulated in the deeper part of the lake, and lacustrine lime in the littoral zone. The difference between the water depths of these two zones was only $2 \mathrm{~m}$. This gives grounds to suggest that lenses of lacustrine lime were formed due to bottom springs, which carried calcium-rich water into the lake. Such a stage is typical of a number of small Estonian lakes (Caapce, 1994).

The oligotrophic stage was followed by the alkalitrophic stage (Late Boreal, Atlantic) during which calcareous deposits accumulated even in the central part of the lake. Commonly it is a sign of a lowering of the lake level, but in the present case the composition of the mollusc fauna contradicts this. Obviously the ground water budget is responsible for the high alkalinity of the lake.

Since the Subboreal organic-rich deposits accumulated with the content of terrigenous material increasing upwards. This was obviously caused by increased erosion due to human activity. Since then the lake started to eutrophicate.

During the Allerød the vegetation was similar to park tundra with birch and grass heath, and more tundra-like during the Younger Dryas. The birch probably survived in the area, but the landscape was open. In the Preboreal birch rapidly expanded, being dominant even in the Boreal. Spruce arrived in the Early Atlantic (or even in the Younger Dryas) and dominated at Päidre during the Subboreal, Early and Middle Subatlantic periods. Oak stands were widely spread in the Early Subboreal. By today almost all QM have been cut down, now only ash forms groves on the slopes of ancient valleys.

Traces of human activity are weak on the pollen diagram. They become more significant since $2700 \mathrm{BP}$. Thus the most important changes in the forest composition were climatically induced and affected by the local factors (soils, tree succession and competition, migration, lags). The paludification of the lake basin started about $6000 \mathrm{BP}$, and was more rapid between $4800-3300 \mathrm{BP}$ and $1700-0 \mathrm{BP}$.

The set of evidences refers to higher lake levels in the Allerød, at the end of the Preboreal, and in the second half of the Boreal, during the Atlantic, and in the middle of the Subatlantic.

\section{ACKNOWLEDGEMENTS}

We are grateful to A. Raukas and A. Miidel for their critical notes. A. Sarv made the pollen analyses, L. Säga the chemical analyses from core No. 45. S. P. Harrison kindly revised the first version of the lake-level change reconstruction. H. Kukk is thanked for improving our English.

\section{REFERENCES}

Andersen, S. Th., Aaby, B. and Odgaard,- B. 1983. Environment and Man. Current Studies in Vegetational History at the Geological Survey of Denmark. J. Danish Archaeology, 2, 184-196. 
Berglund, B. E. 1966. Late-Quaternary vegetation in eastern Blekinge, southeastern Sweden. II. Post-Glacial time. - Opera Botanica, 122.

Berglund, B. E. 1979. Palaeohydrological Changes of the Temperate Zone in the Last 15000 Years. Subproject B. Lake and Mire Environments. Dept. of Quaternary Geology, Lund University.

Grimm, E. C. 1992. Tilia and Tilia-graph: Pollen spreadsheet and graphics programs. - In: Pons, A. (ed.). 8th International Palynological Congress Aix-enProvence. Program and Abstracts. Marseille, 56.

Huntley, B. 1990. European vegetation history: Palaeovegetation maps from pollen data - 13000 yr BP to present. - J. Quaternary Science, 5, 2, 103-122.

Hyvärinen, H. 1987. History of forests in Northern Europe since the last glaciation. In: Eronen, M. (ed.). Dendrochronology around the Baltic. Annales Academie Scientiarum Fennicae, Ser. A. III. Geologica-Geographica, 45, 7-18.

Iversen, J. 1941. Land occupation in Denmark's stone age. - Danmarks geologiske Undersögelse, II. Raekke, 66, 7-68.

Iversen, J. 1958. The bearing of glacial and interglacial epochs on the formation and extinction of plant taxa. - Uppsala Univ., Arsskrift 6, 210-215.

Jaanits, L. 1968. Sakala asustusest kivi- ja pronksiajal. - In: Viljandi rajoonis. Koduuurijate seminar-kokkutulek 25.-28. juuni 1968. Ettekannete kokkuvõtted. Tallinn, $57-61$.

Jaanits, L. 1990. The origin and development of the Kunda culture. - In: Viires, A. (ed.). Finno-Ugric Studies in Archaeology, Anthropology and Ethnography. Tallinn, $7-15$.

Kristiansen, I. L., Mangerud, J. and Lømo, L. 1988. Late Weichselian/Early Holocene pollen- and lithostratigraphy in lakes in the Alesund area, Western Norway. - Review of Palaeobot. and Palyn., 53, 185-231.

Laasimer, L. 1965. Eesti NSV taimkate. Valgus, Tallinn.

Lõokene, E. 1961. Vanadest rannikumoodustistest Sakala kõrgustikul. - In: Geoloogilised märkmed 1. LUS, Tallinn, 52-57.

Lõokene, E. 1979. Viljandi ja Sinialliku järve geoloogiast. - In: Raukas, A. (ed.). Eesti NSV saarkōrgustike ja järvenõgude kujunemine. Valgus, Tallinn, $161-169$.

Lõokene, E., Pirrus, R. 1979. Oisu-Mõonnaste ja Päidre järve geoloogiast. - In: Raukas, A. (ed.). Eesti NSV saarkõrgustike ja järvenõgude kujunemine. Valgus, Tallinn, $170-181$.

Mäemets, A. 1983. Viljandi rajooni järvede keskkonnakaitseline seisund. - In: Ratas, R. (ed.). Väikelinnade ja maa-asulate keskkonnakaitse ning maastikuhooldus. Ettekannete teesid. Tallinn, 69-73.

Mangerud, J., Andersen, S. T., Berglund, B. E. and Donner, J. 1974. Quaternary stratigraphy of Norden, a proposal for terminology and classification. Boreas, 3, 109-128.

Männil, R. 1964. Järvelubja lasundite levik ja stratigraafia Eestis. PhD thesis. Eesti TA Keskarhiiv, Tallinn.

Molloy, K. and O'Connel, M. 1987. The nature of the vegetational changes at about 5000 B.P. with particular reference to the elm decline: Fresh evidence from Connemara, Western Ireland. - New Phytologist, 106, 203-220.

Sats, V. 1983. Sakala kõrgustiku orgjärvede arengust. Diploma paper. Tartu, TU Geograafia kateeder.

Vasari, Y. 1986. The Holocene development of the Nordic landscape. - Striae, 24, 15-19.

Пиррус Р. 1969. Стратиграфическое расчленение позднеледниковых отложений Южной Эстонии по данным спорово-пыльцевого анализа. - Изв. АН ЭССР. Хим. Геол., 18, 2, 181-191.

Саарсе Л. 1976. О составе сапропелевых отложений малых озер Эстонии. - Изв. АН ЭССР. Хим. Геол., 25, 2, 161-168.

Саарсе Л. 1994. Донные отложения малых озер Эстонии. Ин-т геологии АН Эстонии, Таллинн. 
Саapce Л., Сарв А. 1986. Геология долинных озер Сакалаской возвышенности. In: Раукас А., Илометс M. (eds.). Изучение озерно-болотных формаций в целях палеогеографических реконструкций. Тезисы докладов. Таллинн, 106108.

Сарв А., Ильвес Э. 1976. Стратиграфия и геохронология голоценовых озерных и болотных отложений юго-западной части Эстонии. - In: Бартош T. (ed.). Палинология в континентальных и морских геологических исследованиях. Зинатне, Рига, $47-59$.

\section{PÄIDRE JÄRVE (LOUUNA-EESTI) LITO- JA BIOSTRATIGRAAFIA}

Leili SAARSE, Siim VESKI, Atko HEINSALU, Raivo RAJAMAE, Tõnu MARTMA

On esitatud andmed Päidre järve põhjasetete lasuvuse, litoloogilise koostise ja biostratigraafilise liigestuse kohta. Setete koostis ja lasuvus on muutlikud. Basaalsel liivakihil lasub karbonaadi-, ülaosas lehtsamblarikas aleuriit, mis on settinud vastavalt Allerødis, hilises Drüüases ja Preboreaalis. Vetikarikas järvemuda hakkas moodustuma Preboreaali lõpul. Boreaali teisel poolel ja Atlantikumi esimesel poolel settis lubjarikas järvemuda, alates Atlantikumi teisest poolest kuni tänapäevani järvemuda. Päidre järv on oma eksisteerimise ligikaudu 12000 aasta jooksul läbinud neli suuremat arengufaasi, mille jooksul on korduvalt muutunud ka veetase.

\section{ЛИТО- И БИОСТРАТИГРАФИЯ ОЗЕРА ПЯИДРЕ, ЮЖНАЯ ЭСТОНИЯ}

\section{Лейли СААРСЕ, Сийм ВЕСКИ, Атко ХЕЙНАЛУ, Райво РАЯМЯЭ, Тыну MAPTMA}

Представлены новые данные о распространении, лито- и биостратиграфии донных отложений оз. Пяйдре. Последние сложены базальными песками, на которых залегает алеврит с гипновым мхом в верхней части. Эти отложения формировались в аллерёде, позднем дриасе и пребореале. Начало образования водорослевого сапропеля относится к концу пребореала. Во второй половине бореала и в первой половине атлантического периода накапливался карбонатный сапропель, а со второй его половины по настоящее время - органический сапропель. Оз. Пяйдре прошло в своем развитии четыре фазы, в течение которых уровень воды озера менялся несколько раз. 